\title{
PERMASALAHAN KONDISI AIR DALAM LINGKUNGAN HIDUP SAAT INI
}

\author{
Muhammad Maulana \\ Program Studi Pendidikan IPS \\ Fakultas Keguruan dan Ilmu Pendidikan \\ Universitas Lambung Mangkurat \\ Banjarmasin \\ Email: 2010128210006@mhs.ulm.ac.id
}

\begin{abstract}
Abstrak
Pada masa kini Air memiliki unsur pokok sangat penting di kehidupan manusia atau dalam kalangan masyarakat sekitar yang menjadikan sebagai nilai guna bagi kehidupan seharihari untuk menunjang keberlangsungan hidup sekaligus air sangat paling utama mencapai dalam kebutuhan setiap utama bagi proses kehidupan ini. Tujuan penulisan artikel ini membahas tentang permasalahan kondisi air dalam lingkungan hidup saat ini saat krisis air menjadi bahan topik pembicaraan di kalangan masyarakat Indonesia hari semakin hari diperhatikan makin banyak permasalahan. Metode menggunakan penelitian kualitatif pada dasarnya merupakan penelitian yang berdasarkan studi literatur. Penelitian kualitatif ini dengan mencari studi perpustakan mengumpulkan jurnal, dokumen, serta skripsi yang Penelitian ini mendeskripsikan hasil paparan dari jurnal, buku serta refrensi lainnya. Hasil penulisan artikel ini untuk mengetahui kaitannya dengan permasalahan air dengan unsur dari pencemaran tersebut.
\end{abstract}

Keywords : Permasalahan air, lingkungan hidup, kondisi air

\section{Pendahuluan}

Pada masa kini Air memiliki unsur pokok sangat penting di kehidupan manusia atau dalam kalangan masyarakat sekitar yang menjadikan sebagai nilai guna bagi kehidupan seharihari untuk menunjang keberlangsungan hidup sekaligus air sangat paling utama mencapai dalam kebutuhan setiap utama bagi proses kehidupan ini. Pada dasaranya air yang paling berlimpah di alam, (Herlina, N. (2017). namun dalam setiap tahun nya sejalan dengan keberlangsungan waktu dan tingkat taraf kehidupan manusia sangat membutuhkan air sebagai sumber dikehidupan kota maupun desa jumlah air yang bisa dijumpai dimuka bumi ini termasuk dalam relatif sangat teratur, (Mutiani, M. (2015). meskipun air banyak mengalami pergerakan yang menimbulkan arus karena dipengaruhi oleh iklim atau cuaca dan bisa juga 
mengalamai berubah bentuk. dalam sirkulasi nya tersebut air melakukan perubahan menjadi uap yang dikarenakan mengikuti sirkulasi pada tanaman, tubuh manusia dan hewan (Herlina, N. (2017)., yang pada dasarnya dalam teori ilmu air merupakan sumber alam yang bernilai sangat ekonomis dan tinggi yang dipandang melalui ilmu biologis maupun budaya tentang lingkungan.

Disetiap aspek kehidupan air banyak digunakan sebagai alat penunjang seperti transportasi, Manik, K. E. S. (2018). sebagai pembangkit energi dalam berbagai bidang skalanya, yang dimana katanya air sangat identik pada kehidupan individu meskipun kadar dalam air saat ini mulai tercemar yang dimana proses tersebut banyak individu dan masyarakat menghiraukan penyediaan air dan tentang akan keadaan air dan tidak tau akan sebab akibatnya yang tanpa disadari menimbulkan banyak pencemaran pada air tersebut akan merusak ekosistem sungai maupun laut dikarenakan individu dan masyarakat tidak peduli dengan kelestarian ekosistem air yang saat ini susah didapatkannya air bersih yang dikarena banyak kerusakan lingkungan hidup yang mengakibatkan air juga ikut terkontaminasi tercemar.

Pada saat krisis air menjadi bahan topik pembicaraan di kalangan masyarakat Indonesia hari semakin hari diperhatikan makin banyak permasalahan yang timbul di wilayah Indonesia terutama provinsi padat dengan penduduknya tentang masalah khususnya air yang terkena limba dari berbagi hasil kegiatan manusia, (Machdar, I. (2018). sehingga sekaligus kualitas dasar dari kebutuhan untuk memenuhi yang terus meningkat dikarenakan oleh seperti limbah dari pabrik, rumah tangga atau perumahan dan pertanian yang menjadikan pemerosotanya kadar kualitas air akibat dari penabangan liar yang menjadi bekuranganya kualitas air serta berubahnya pemanfaatan lahan dikota dan semakin menyusutunya pemasukan air pada beberapa sungai diwilayah pulau Kalimantan selatan ini. yang pada dasaranya menimbulkan dampak bencana dimana terjadinya dikarenakan oleh akibat minimnya air pada saat seperti dimusim kemarau disertai banyaknya kotoran yang tertumpuk. Jadi Tujuan penulisan artikel ini membahas tentang permasalahan kondisi air dalam lingkungan hidup saat ini saat krisis air menjadi bahan topik pembicaraan di kalangan masyarakat Indonesia hari semakin hari diperhatikan makin banyak permasalahan.

\section{Metode}

Pada penulisan Aritikel ini memakai penelitian kualitatif. dimana artikel disajikan secara deskriptif dan penelitian kualitatif pada dasarnya merupakan penelitian yang 
berdasarkan studi literatur. penelitian kualitatif ini dengan mencari studi perpustakan mengumpulkan jurnal, dokumen, serta skripsi yang berkaitan dalam permasalahan lingkungan hidup masyarakat berdasarkan kondisi bau air, suhu, keruh air, serta warna yang berdasarkan pencemarannya kemudian dikaitkan dengan sebab terjadinya perlimbahan dari air. Penelitian ini mendeskripsikan hasil paparan dari jurnal, buku serta refrensi lainnya, untuk mengetahui kaitannya dengan permasalahan air dengan unsur dari pencemaran tersebut.

\section{Pembahasan}

Dalam lingkungan hidup individu atau manusia sudah mengenal dengan namanya pencemaran air yang dapat dikatakan dengan kerusakan ekosistem pada air banyak sekali istilahnya yang bisa diartikan banyak orang seperti polusi air, Arisanty, D. (2018). Pada dasarnya pencemaran air itu bahwasanya dari pencemaran lingkungan yang telah diartikan atau sudah didefinisikan, dalam kajian ilmu lingkungan hidup pencemaran ini tidak mungkin bisa ada ditunjukan secara nyata yang mana bahwasanya sebagai sebuah pencemaran dari komponen yang berada dilingkungan tersebut yang mana pencemaran air laut dan air, tanah serta udara.

Pencemaran pada bahwasanya air yang didefinisikan berdasarkan suatu penyebab terjadinya tercemarnya lingkungan makhluk hidup dari zat kimia energy dari komponen lainnya kedalam air yang mengakibatkan kualitas air menjadi sangat buruk menimbulkan banyak masalah dan nampak kondisinya menjadikan pokok permasalahan dalam kehidupan, (Machdar, I. (2018). asal dari pemasukan unsur air yaitu akibat dari limba yang setiap hari dibuang sehingga menumpuk yang menjadikan kerusakan sangat besar, namuk aspek dari penyebab pelaku dapat yang disebabkan utama oleh manusia sendiri, adapun pencemaran air karena alam tidak bisa berimplikasi dengan keadaan secara langsung, dan aspek dari akibat yang bisa diperhatikan pada aspek dari penurunan berkualitasnya air sampai ketingkat sudah ditentukan pada dasarnya dalam definisi ini merupakan tingkat kadar air menjadi tepi dasar antara tingkat tercemar.

Air bersih dan yang aman dikonsumsi itu memiliki mutu sesuai dengan kriteria bagi air tersebut yang mana semisalnya air yang dapat diminum itu memiliki kriteria yang langsung dengan mutu atas dikarenakan yang mana memiliki kriteria yang sangat berbeda dengan air yang dapat dipakai secera langsung seperti air baku air yang memiliki mutu menengah dan mutu sedang yang mana untuk keperluan perikanan dan peternakan dan air taraf kebawah 
tersebut dalam keperluannya pertanian didesa serta usaha pada diperkotaan, seperti perindustrian lokal dan pembangkit tenanga air, yang dimana terkandung arti bahwa air minum yang dikonsumsi masyarakat, (Manik, K. E. S. (2018). harus memenuhi syarat dalam taraf pemakaiannya maupun pada kuantitas air tersebut, yang mana menjadi tentang salah satu peraturan mentri kesehatan yang mana pada dasarnya dijelaskan tentang pengawasan tingkat air yang untuk diminum dan air bersih untuk dipakai sehari-hari.

Jadi didefinisi ini menjelaskan tentang arti air dan mutu dalam lingkungan kehidupan yang mana dapat disimpulkan air itu menjadi kegunaan yang sangat penting pada masyarakat dan memiliki arti penting yaitu dengan pendefinisi pencemaran air yang disimpulkan memiliki pengertian yang mana telah adanya pemasukan para makhluk hidup seperti zat, energy dan atau komponen lain ke air yang bahwasanya tersebut akan menjadikan kegiatan manusia terus menerus yang memiliki suatu kualitas air turun ketingkat tertentu yang menyebabkan air tidak berfungsi lagi dan sesuai keadanya. Yuniarti, Y., \& Biyatmoko, D. (2019).

Sebab terjadinya akan suatu pencemaran air makhluk hidup terutama manusia sangat membutuhkan air dikehidupannya untuk kelangsungan hidupnya yang paling utama air untuk minum. Dalam bagian siklus dari global, memiliki guna dari ruang abiotik dan biotik, menjadikan siklus menjadi tepangaruh oleh aksi atau aktivitas manusia dalam pemakaian air dan pembuangnya, (Arisanty, D. (2018). proyeksi dalam perubahan iklim sangat berdampak dengan pengembangan industri di kota yang mana akan mengancam keberlangsungan kualitas air minum saat ini dan ketersediannya menjadi yang paling utama digunakan, populasiserta pemakaian dan pembuangan bahwasanya dari asal meningkatnya seakan tidak ada pembatasan dalam pemasukkan air yang mana dikarenakan dalam upaya perkembanga atas pendekatan yang lumayan memiliki jangka bertahun-tahun lamanya untuk pemakaian air yang terus menerus membutuhkan pengelolaan yang bagus serta efektif.

Kerusakan akan menjadi penurunan dari sumber daya air itu sendiri yang mana terjadi dan semakin rusaknya dari ketahun. yang mana bahwasanya harus ada upaya demi langkah dalam pengatasan yang ada di Indonesia yang menjadikan permasalahan itu mana banyaknya terlakukan tetapi rusaknya dari sumber air itu sudah rusak dan berjalan dengan cepat yang mana bisa saja tidak terkira kapan pun, Arisanty, D. (2018). pencemaran ini yang memliki penyebab saat ini terjadi hamper semua kota besar di wilayah yang ada di Indonesia sendiri dan sudah berlangsung dalam kurun ratusan tahunnya. Dalam pengalamanya negara yang sangat maju akan melakukan adanya revolusi industri 150 ditahun yang lalu, namun negara tersebut 
memberika rasa yang fokus dan optimis. Bahwasanya tetap ada kesempatan yang mana pada dasarnya negara yang masih berkembang melakukan aksi untuk menanggulangi dan memikirkan pencemaran terjadi saat dinegara tersebut, pada dasarnya akal penanggulangannya pencemarana, bahwasanya air perlu kita kenali lebih utama dari mana asal dari sumber pencemarannya yang mana bahwasanya bahan pencemaran, bersifat berbau dari bahan kotor atau rusak, kemudian dilaksanakannya pengambilan aksi atau inisiatif dalam mengatasi pencemaran.

Penyebab dalam pencemaran pada air menimbulkan banyak masalah memiliki akibat tingginya penyakit berbasis lingkungkan perkotaan pada dasarnya dalam konteksnya sendiri banyak nya tidak terpenuhinya kebutuhan yaitu air bersih, (Machdar, I. (2018). Pada unsur penelitian dalam kegunaan jamban yang bersifat masih rendah, serta bisa menyebabkan air, udara serta tanah didasari oleh limbah rumah tangga, dan limbah akan pabrik industri serta dari pertanian yang meakibatkan dalam pemakaian alat prasarana serta keadaan dalam lingkungan tersebut yang mungkin akan berkembangnya vektror. pada kegunaan penyedian akan air bersih yang tidak bisa memenuhi persyaratan juga memikiki inti pokok permasalahan akan yang perlu mendapat bantuan dan banyak di temui dalam masyarakat.

Penyebab cemaran dari mikrobiologis yang terjadinya pada letak buang dan jarak antara tempat buang air besar dan kecil, berada adanya mikroba atau kuman akan menyebabkan tepengaruhnya oleh keadaan lingkungan sekitar rumah atau pemukiman penduduk (Machdar, I. (2018). Jarak antara jamban yang memiliki masalah akan pencemar lain yang mana sangat dekat sekali dengan sumur galian yang mana akan menambahkan adanya kerusakan ataupun tercemaranya pada air yang terletak disekitar wadahnya tidak bersih akan meningkatnya akan keberadaan kuman, mikroba. Adapun bakteri atau kuman coliform yang disebabkan oleh kegiatan adanya limbah yang bersih atau baik yang berawal dari suatu perlimbahan domestic maupun dari pabrik industri, yang mana bahwasanya bahan pembuangan organik yang berasal dari perlimbahan pabrik industri maupun dari rumah tangga pada dasarnya berupa perlimbahan menjadi pembusukan dan terdegradasinya oleh bahan bahan mikro organisme tersebut yang menjadikan hal itu bisa mengakibatkan dampak semakin banyaknya pun mikro tersebut, yan mikroba pathogen pun juga ikut dalam berkembang biak hal ini bisa mendampak dan mengakibatkan berbagai hal penyakit di air.

Meningkatnya penyedian air selalu meningkat seiring dengan zaman dengan kemajuan dan peningkatannya taraf dari kehidupan manusia sendiri, dan juga banyak dampak yang 
turunnya akan jaminan atas mutu pada air minum berakibatkan menimbulkan akan ruginya yang sangat besar untuk kesehatan, (warmansyah abbas, e. r. s. i. s. (2018). bahwasanya ini sejalan adanya penelitian yang semakin berkembanganya banyaknya wilayah permukiman kurang mendukunng akitivasnya dengan baik bisa akan mengakibatkannya jalannya pembuangan perlimbahan dari rumah seperti pembuangan perlimbahan kamar mandi serta tempat buang air besar maupun dapur rumah permasalahan ini membuat air menjadi terkuras mutu nya yang bisa saja meakibatkan terkoordinasi dengan tidak baiknya pontesi dasar air untuk warga mudah sekali dapat tercemar. perlimbahan ini bahwasanya akan cepat sekali berdampak buruk oleh cemaran nya seperti air maupun tanah yang mungkin bisa berdampak terjadinya sebaran berupa penyakit bakteri yang bisa menular.

Jalan salah satu nya yang bisa dilakukan untuk mengatasi pencemaran ini warga harus melakukan alternatif aturan yang dilakukan adanya kegunaan air pada sumur dengan bersamaan yang mana penggunaan sumur yang telah dibor tidak terjadi banyak cemaran oleh kuman sehingga sangat bisa saja dapat dipakai untuk air yang akan minum dengan adanya sumur bor kebutuhan air minum dimasyarakat akan terpenuhi. Yuniarti, Y., \& Biyatmoko, D. (2019).

Permasalahan yang banyak dan isu isu tentang pembuangan tinja dan air bersih didaerah lingkungan tersebut sehingga masyarakat harus memiliki inisiatif untuk merencanakan sebuah tangki septik yang terletak dibantaran, pelaksanaan ini direncanakan karenakan perlahan yang semakin banyak di tempati oleh banyaknya penduduk padat dan tempat untuk perencanaan tangki obat septik dihalaman rumah yang mana telah terlaksananya untuk menghindari akan terjadinya masalah pada lingkungan kehidupan, (Deasy, A. (2017). mulai nya adanya permasalahan dari kesehatan dilingkungan makhluk hidup, yang mana bahwasanya untuk pengurangan biaya pembersihan dan pengurasaan. Perindustrian pun mulai meningkat semakin sejalan dengan waktu yang menyebabkan terjadinya pencemaran air yang dimana isu tersebut bisa saja diatasi dengan dilakukannya pendirian Instalasi pengolahan air limbah aksi ini mencegah dari terjadinya tercemarnya air bersih sumur galian.

Dalam penyebab pencemaran air ini perlu adanya tindakan yang pasti dari selurus masyarakat untuk menangani dan perbaikan tingkat kegunaan perairan yang mana bahwasanya saat ini direncanakan dari diri kita sendiri secara tegas dan segan memandang lingkungan hidup sebagai wadah suatu kesatuan yang mana tidak bisa terlepaskan dari makhluk hidup seperti manusia yang harus menaati segala aturan yang berlangsung agar kerusakan lingkungan tidak 
berkelanjutan. Yuniarti, Y., \& Biyatmoko, D. (2019). kondisi dalam kualitasnya air yang tdiak terpengaruhi dengan kondisi akan perubahan dari tanah. yang mana bahwasanya bisa saja terjadi mengalami banyaknya pengubahan yang cepat dalam takaran sebuah air di bawah tanah mengakibatkan pembasahan serta akan keringnya proses dari pembahasan dan pengeringan tersebut sering terjadi dikarenakan pada negara Indonesia memilliki iklim tropis yang bersifat berubah ubah sifat fisiknya seperti prositas, angka pori, kepadatan kering.

Indikator pencemaran ini yang pada umum diketahui pada pemeriksaan dari penelitian agar melihat pencemaran air dari $\mathrm{pH}$ nya sendiri atau fokus pada sumber hydrogen akan oksigen dan ion yang terlarut, kebutuhan oksigen biokimia serta kebutuhan oksigen kimiawi. Yuniarti, Y., \& Biyatmoko, D. (2019). indikator memiliki penanda air dalam tempat hidup telah terjadinya tercemarnya dikarenakan suatu perubaan atau penanda yang mana bisa kita amati yang tergolongkan seperti :

- Pengamatan yang melakukan dengan cara fisis, yang mana diamatilah untuk ini tujuan penelitian tentang air didasari oleh ketingkatan kebersihan akan air atau pengeruhan air, berubahnya suhu yang menjadikan perubaan pada warna dan bau rasa.

- Penelitian serta yang telah direncanakan secara proses kimiawi, yang mana bahwasanya pengamtan tercemarnya pada air berdasarkan kimia yang berlarut dalam pengubahan $\mathrm{pH}$

- Penelitian mengunakan secara sains biologis, melaukan pengmatan tercemarnya pada air didasari oleh mikro organisme yang mana akan terdapat dalam air tersebut adanya sebuah kuman bakteri pathogen

Jadi dengan demikian oksigen akan dibutuhkan sangat penting karena bahwasanya didasari oleh adanya micro organisme ruang lingkup hidup air yang mana dikendalikan untuk memecahkan bahan pembuangan pada organik didalam air berubah menjadi karbindioksida. Jadi proses karbon oksidasi bahan pada organik berlangsung secara lama.

Sumber cemaran sering menjadi sumber penyakit pada umum dikarenakan sumber air itu yang akan diminum oleh manusia harus ada syarat sebuah lokasi serta konstruksi. lokasi meinginkan adanya agar dari mana awal mata air yang diminum tercegah dari kuman maupun pengotoran lain nya. Machdar, I. (2018). Jadi perlu adanya perhatian dan pengatahuan sumber terjadinya pencemaran air yang mana jarak perlu ada jarak dengan tempat buang air kecil 
maupun besar, dilubang penggalian sampah dan tempat penggalian untuk air perlimbahan serta pengotoran.

Adanya titik tujuan tercemarnya sebuah air yang meakibatkan mutu atau taraf air yang disebabkan adanya proses perubahan yang terajdinya pada tanah yang mana bahwasanya air itu sendiri, memiliki penyaringan atau pembersihan partikel kuman akan terjadi pada air, caranya dengan pemisahan bahan yang kotor seperti sampah yang telah tedeksi kuman yang terdapat pada air. Mahyudin, R. P. (2017). awal dari aliran air berjalan dan melewati pengecekan sehingga akan hilanganya pada proses tersebut akan meakibatkan mutu dalam tarafnya sendiri yang mana bahwasanya melakukan proses adany perubahan yang terjadi.

Sebab dalam penyebab dari mana awal tercemarnya pada air, tetapi secara dalam kaidahnya dapat dikatakan untuk pengkategorikan menjadikan dua buah sebab yaitu rusaknya langsung dan tidak langsung, potensi bertujuan menutupi efluen untuk keluar dari pabrik industri, tempat sampah, rumah dan lain nya, (Putro, H. P. N., \& Jumriani, J. (2020). yang mana bahwasanya potensi tak langsung yang mengarah pengelolahan yang mulai masuk lewat aliran air dari tanah, jadi bahwasanya adapun tentang atmosfir berupa hujan, pada hakikatnya memiliki sebab utama dalam permasalahan ini yang akan berasal dari pabrik atau gudang perindustrian, rumah yang mana terletak dalam pemukiman wilayah yang dekat pertanian, air maupun tanah yang mengandung sisa dari aktivitas manusia yang pada dasanya pencemaran terhadap akan udara yang menyebabkan hujan asam.

Barang buang seperti minyak dituangkan diair akan menuju kelingkungan hidup akan terlihat serta menutupi permukan pda air. bahwasanya pembuangannya minyak yang memiliki senyawa dari bahan volatile bisa saja terjadi naik nya penguapan serta luasnya pada minyak menutupi permukaan dari air akan semakin sedikit (Sanjaya, R. E. (2020). Dalam penyusutan ini minyak mengikuti pada waktunya sendiri maka minyak pada dataran air dapat terdegradasi atau hancur dikarenakan penyeba mikro organisme tertentu. Tetapi membutuhkan banyak perwaktu yang mana mungkin cukup lama. bagian minyak yang dibuang keair bisa menggaunggu mikro organisme dalam ruang lingkup air, akan tetapi bagian tersebut akan membantengi diffuse oksigen pada udara, maka oksigen akan berkurang, bagian tersebut akan melindung dari sinar matahari yang masuk, adapun fotosintesa akan terhalang, yang mana habitats dari burung juga akan terhalang tentang ekosistemnya. Bahan buangan dari zat kimia yag dikelompokkan menjadi : 
A. Sabun atau deterjen, sampo dan bahan pembersih lain

B. Bahan pemberantas hama insektisida

C. Zat radioaktif

D. Zat warna kimia

Jadi sumber dari hasil penulisan pencermarannya yang membuat ekosistem air terganggu sangat tidak baik bagi kesehtan, dan akhirnya berakibat pada pembangunan ekonomi, (Putro, H. P. N., \& Jumriani, J. (2020). sebab kekurangna air dapat menjadi ancaman berlangsungannya lingkungan kehidupan dan berpengaruh kegenerasi yang akan datang yang mana sudah dtinjau dari segi mutu dan kualiti nya dan kuantitasnya pada dasarnya air makin menurun dan berkembanganya berbagai unsur dari penyakit akan tingginya angka tecemar nya air disebabkan perlimbahan pabrik industri yang tidak diolah dahulu serta perlimbahan rumah yang dibuang kebadan aliran sungai.

\section{Simpulan}

Masa kini Air memiliki unsur pokok sangat penting di kehidupan manusia atau dalam kalangan masyarakat sekitar yang menjadikan sebagai nilai guna bagi kehidupan sehari-hari untuk menunjang keberlangsungan hidup sekaligus air sangat paling utama mencapai dalam kebutuhan setiap utama bagi proses kehidupan ini. Pada saat krisis air menjadi bahan topik pembicaraan di kalangan masyarakat Indonesia hari semakin hari diperhatikan makin banyak permasalahan yang timbul di wilayah Indonesia terutama provinsi padat dengan penduduknya tentang masalah khususnya air yang terkena limba dari berbagi hasil kegiatan manusia.

Pencemaran air yang didefinisikan berdasarkan suatu penyebab terjadinya tercemarnya lingkungan makhluk hidup dari zat kimia energy dari komponen lainnya kedalam air yang mengakibatkan kualitas air menjadi sangat buruk menimbulkan banyak masalah dan nampak kondisinya menjadikan pokok permasalahan dalam kehidupan. krisis air dan permasalahan kondisinya juga menjadi bahan topik pembicaraan di kalangan masyarakat Indonesia hari semakin hari diperhatikan makin banyak permasalahan yang timbul di wilayah Indonesia terutama provinsi padat dengan penduduknya tentang masalah khususnya air yang terkena limba dari berbagi hasil kegiatan manusia, sehingga sekaligus kualitas dasar dari kebutuhan untuk memenuhi yang terus meningkat dikarenakan oleh seperti limbah dari pabrik, rumah tangga atau perumahan dan pertanian yang menjadikan pemerosotanya kadar kualitas air akibat dari penabangan liar.

\section{Daftar Pustaka}


Arisanty, D. (2018). Pemberdayaan Perempuan Pada Kawasan Wisata: Studi Pada Pasar Terapung Lok Baintan.

Deasy, A. (2017). Dampak Bencana Banjir Terhadap Kondisi Sosial Ekonomi masyarakat di Kecamatan Batu Benawa Kabupaten Hulu Sungai Tengah, Kalimantan Selatan. JPG (Jurnal Pendidikan Geografi), 4(4), 42-52.

Hasibuan, R. (2016). Analisis dampak limbah/sampah rumah tangga terhadap pencemaran lingkungan hidup. Jurnal Ilmiah Advokasi, 4(1), 42-52.

Herlina, N. (2017). Permasalahan lingkungan hidup dan penegakan hukum lingkungan di Indonesia. Jurnal Ilmiah Galuh Justisi, 3(2), 162-176.

Machdar, I. (2018). Pengantar Pengendalian Pencemaran: Pencemaran Air, Pencemaran Udara, dan Kebisingan. Deepublish.

Manik, K. E. S. (2018). Pengelolaan lingkungan hidup. Kencana.

Mahyudin, R. P. (2017). Kajian Permasalahan Pengelolaan Sampah dan Dampak Lingkungan di TPA (Tempat Pembuangan Akhir). Jurnal teknik lingkungan, 3(1).

Putro, H. P. N., \& Jumriani, J. (2020). Kehidupan Sosial Dan Ekonomi Masyarakat Bantaran Sungai A Sebagai Sumber Belajar Ips.

Sanjaya, R. E. (2020). Kualitas Air Sungai Di Desa Tanipah (Gambut Pantai), Kalimantan Selatan. Kualitas Air Sungai Di Desa Tanipah (Gambut Pantai), Kalimantan Selatan.

Susanto, B., Krisdianto, K., \& Satria, H. (2018). Kajian kualitas air sungai yang melewati Kecamatan Gambut dan Aluh Aluh Kalimantan Selatan. Bioscientiae, 6(1).

Yuniarti, Y., \& Biyatmoko, D. (2019). Analisis Kualitas Air Dengan Penentuan Status Mutu Air Sungai Jaing Kabupaten Tabalong. Jukung (Jurnal Teknik Lingkungan), 5(2). 